\title{
Reaction of peach tree genotypes to bacterial leaf spot caused by Xanthomonas arboricola pv. pruni
}

\author{
José Gilberto Sousa Medeiros ${ }^{1}$; Idemir Citadin²*; Idalmir dos Santos²; André Paulo \\ Assmann ${ }^{3}$ \\ ${ }^{1}$ UTFPR - Programa de Pós-Graduação em Agronomia. \\ ${ }_{3}^{2} U T F P R$ - Depto. de Agronomia, C.P. 571 - 85503-390 - Pato Branco, PR - Brasil. \\ ${ }^{3}$ Agropantanal, R. Campo Grande, 1190 - 79560-000 - Chapadão do Sul, MS - Brasil. \\ *Corresponding author <idemir@utfpr.edu.br>
}

\begin{abstract}
Bacterial leaf spot (BLS), caused by Xanthomonas arboricola pv. pruni, is one of the most important diseases in Brazilian peach [Prunus persica (L.) Batsch] orchards and all over the world. The main objective of this study was to evaluate for BLS sensitivity of peach genotypes. Evaluations of thirty genotypes were carried out during the onset of the disease, for incidence, severity and defoliation, in field conditions. Pearson's correlations between the percentage of defoliation and leaf severity rating were performed. Genotypes 'Conserva 985', 'Conserva 871', 'Conserva 1129', and 'Tropic Snow', as resistance sources, and 'Conserva 1153', 'Bonão', 'Conserva 1125', and 'Atenas', as susceptible to BLS, were submitted to detached-leaf bioassay and greenhouse evaluation. The peach genotypes showed different reactions to the BLS, and none was immune to the pathogen. 'Conserva 985' and 'Conserva 1129' confirmed resistance responsiveness while 'Conserva 1153', 'Conserva 1125' and 'Atenas' were found susceptible for the detached-leaf bioassay.
\end{abstract}

Key words: disease resistance, disease severity

\section{Reação de genótipos de pessegueiro a mancha foliar causada por Xanthomonas arboricola pv. pruni}

\begin{abstract}
RESUMO: A bacteriose foliar causada por Xanthomonas arboricola pv. pruni é uma das mais importantes doenças do pessegueiro [Prunus persica (L.) Batsch] no Brasil e no mundo. Avaliou-se a sensibilidade de genótipos de pessegueiro a $X$. arboricola pv. pruni. Trinta genótipos foram avaliados em campo, quanto à incidência, severidade e desfolha causada pela bactéria. Calculou-se a correlação entre desfolha e severidade da doença. A partir dos resultados obtidos em campo, foram selecionados quatro genótipos resistentes ('Conserva 985', 'Conserva 871', 'Conserva 1129' e 'Tropic Snow') e quatro suscetíveis ('Conserva 1153', 'Bonão', 'Conserva 1125 ' e 'Atenas') para serem novamente avaliados pelo bioensáio com folhas destacadas e em casa de vegetação. Os genótipos diferiram quanto a reação ao patógeno, não sendo observada imunidade. Confirmou-se a resistência para 'Conserva 985' e 'Conserva 1129' e a suscetibilidade para 'Conserva 1153', 'Conserva 1125' e 'Atenas', pelo bioensáio com folhas destacadas.

Palavras-chave: resistência à doença, severidade de doença
\end{abstract}

\section{Introduction}

Bacterial leaf spot (BLS) caused by Xanthomonas arboricola pv. pruni (Smith) is a serious disease where peaches and nectarines [Prunus persica (L.) Batsch] are grown in warm, humid environments with strong winds (Werner et al., 1986). These conditions are typical in the main peach growing regions of Brazil (Nogueira and Rodrigues Neto, 1982) where chemical control is costly and often ineffective. The disease symptoms appears on the lower surface on peach leaves as small, pale-green to yellow, circular or irregular areas with a light-tan center (EPPO, 2006). These spots soon become evident on the upper surface as they enlarge, becoming angular and darkening to deep-purple, brown or black. The surrounding tissue may become yellow. Spots are usually concentrated towards the leaf tip. In Brazil, the greatest damage for peach plants is severe defoliation, although the disease can also affect peach fruit, but it is not usually observed on peach twigs. Screening Prunus spp. for BLS resistance has already been initiated in North America (Scorza and Sherman, 1996) and Brazil (Raseira and Nakasu, 1998) and resistant cultivars are available (Keil and Fogle, 1974; Kretzschmar et al., 1998), but large variability in leaf and fruit resistance levels has been observed (Keil and Fogle, 1974; Rom and Moore, 1979; Werner et al., 1986). Moreover, many of the cultivars rated as highly resistant, become susceptible when submitted to favorable conditions for infection in different agroclimates (Werner et al., 1986).

Host plant resistance is the most economic and sustainable approach for its direct commercial utilization. Thus, the objective of this work was to screen peach genotypes for sensitivity to $X$. arboricola pv. pruni. 


\section{Material and Methods}

Three experiments were conducted from 2006 to 2008 at Pato Branco, Paraná State - Brazil, $\left(26^{\circ} 10^{\prime} \mathrm{S}\right.$; $52^{\circ} 41^{\prime} \mathrm{W}$, $764 \mathrm{~m}$ a.s.1.). The meteorological observations carried out during the evaluation period are summarized in Table 1.

Experiment I - Trees under field conditions: During the 2006/2007 growing season, 22 genotypes were evaluated (Table 2) and during 2007-2008 eight additional genotypes were included (Table 3 ). The trees were 3 and 4 years old in 2006 and 2007, respectively. Each genotype was represented by three plants on a completely randomized design. Five shoots around the canopy were selected for leaf analysis, in each plant. Monthly data on incidence (percent of leaves with BLS symptoms) and severity (percent of damaged leaf area) were recorded in both growing seasons. Data were collected five times between November and March. The evaluation of severity was based on the scale proposed by Citadin et al. (2008). In March, after the last evaluation for disease incidence and severity, the shoots were excised and the percent of defoliation was also recorded. The orchard received standard fungicides and insecticides sprays, similar to what is used in commercial orchards. None of the used pesticides control BLS disease.

Based on the incidence and severity of BLS data collected from November to March of both years, a disease progress curve was constructed, and the area under the disease progress curve (AUDPC) was calculated for each genotype (Campbell and Madden, 1990). AUDPC was estimated using the following equation:

AUDPC $=\sum_{i}^{n-1}\left(\frac{y_{i}+y_{i+1}}{2}\right)\left(t_{i+1}-t_{i}\right)$

in which: $n$ is the number of evaluations made, $y$ is the disease measurement (severity or incidence) and $t$ is time in days.
Table 2 - Area under the disease progress curve (AUDPC) for incidence, severity and percentage of defoliation caused by Xanthomonas arboricola pv. pruni in peach genotypes under natural conditions in 2006/2007.

\begin{tabular}{|c|c|c|c|}
\hline Genotypes & $\begin{array}{l}\text { AUDPC } \\
\text { Incidence }\end{array}$ & $\begin{array}{l}\text { AUDPC } \\
\text { Severity }\end{array}$ & Defoliation \\
\hline & & & $\%$ \\
\hline Conserva 1153 & $10,046.5 \% \mathrm{a}$ & $1276.7 * a$ & $92.9 * \mathrm{a}$ \\
\hline Conserva 1070 & $7,339.3 \mathrm{~b}$ & $373.9 \mathrm{c}$ & $82.5 \mathrm{a}$ \\
\hline Cascata 1063 & $9,290.4 \mathrm{a}$ & $505.6 \mathrm{c}$ & $81.7 \mathrm{a}$ \\
\hline Conserva 1187 & $11,230.6 \mathrm{a}$ & $883.7 \mathrm{~b}$ & $81.7 \mathrm{a}$ \\
\hline Conserva 1223 & $9,380.8 \mathrm{a}$ & $609.6 \mathrm{~b}$ & 77.9 a \\
\hline Atenas & $10,268.1 \mathrm{a}$ & $709.6 \mathrm{~b}$ & $77.3 \mathrm{a}$ \\
\hline Conserva 844 & $8,834.5 \mathrm{a}$ & $363.1 \mathrm{c}$ & $77.0 \mathrm{a}$ \\
\hline Conserva 1127 & $11,192.5 \mathrm{a}$ & $910.6 \mathrm{~b}$ & $75.7 \mathrm{a}$ \\
\hline Tropic Beauty & $10,144.5 \mathrm{a}$ & $370.6 \mathrm{c}$ & $72.5 \mathrm{a}$ \\
\hline Bonão & $11,834.6 \mathrm{a}$ & $538.4 \mathrm{c}$ & $72.0 \mathrm{a}$ \\
\hline Olímpia & $10,425.9 \mathrm{a}$ & $397.6 \mathrm{c}$ & $70.1 \mathrm{a}$ \\
\hline Conserva 1125 & $11,454.9 \mathrm{a}$ & $749.1 \mathrm{~b}$ & $65.8 \mathrm{a}$ \\
\hline Conserva 655 & $7,426.3 \mathrm{~b}$ & $437.0 \mathrm{c}$ & $62.6 \mathrm{a}$ \\
\hline Conserva 1205 & $9,970.2$ a & $289.8 \mathrm{c}$ & $57.8 \mathrm{a}$ \\
\hline Conserva 688 & $7,469.8 \mathrm{~b}$ & $427.0 \mathrm{c}$ & $52.8 \mathrm{a}$ \\
\hline Conserva 977 & $4,024.6 \mathrm{c}$ & $145.9 \mathrm{c}$ & $48.3 \mathrm{~b}$ \\
\hline Conserva 962 & $4,464.4 \mathrm{c}$ & $106.5 \mathrm{c}$ & $38.1 \mathrm{~b}$ \\
\hline Rubimel & $5,435.6 \mathrm{c}$ & $140.9 \mathrm{c}$ & $35.1 \mathrm{~b}$ \\
\hline Conserva 1129 & $5,655.7 \mathrm{c}$ & $190.7 \mathrm{c}$ & $27.4 \mathrm{c}$ \\
\hline Tropic Snow & $3,056.1 \mathrm{c}$ & $68.7 \mathrm{c}$ & $24.9 \mathrm{c}$ \\
\hline Conserva 871 & $4,330.7 \mathrm{c}$ & $102.0 \mathrm{c}$ & $18.5 \mathrm{c}$ \\
\hline Conserva 985 & $3,766.8 \mathrm{c}$ & $98.1 \mathrm{c}$ & $14.8 \mathrm{c}$ \\
\hline Mean & $8,047.4$ & 440.7 & 59.4 \\
\hline CV. (\%) & 15.2 & 54.0 & 22.2 \\
\hline
\end{tabular}

"Means in the same column followed by different lowercase letters differ $(p \leq 0.05$, Scott-Knott test).

Table 1 - Average, minimum and maximum monthly temperatures, average relative humidity, monthly precipitation, and rainy days, during the disease evaluation period (November until March) in both growing season (2006/ 2007 and 2007/2008). Data registered in Pato Branco, state of Paraná, Brazil (2607’ S, 5141' W, 700m a.s.1.).

\begin{tabular}{llcccccc}
\hline Cycle & & Nov. & Dec. & Jan. & Feb. & March & Average \\
\hline \multirow{5}{*}{$2006 / 2007$} & 21 & 23.3 & 23.1 & 22.7 & 22.4 & 22.5 \\
& Average temperature $\left({ }^{\circ} \mathrm{C}\right)$ & 16.3 & 18.6 & 19.5 & 18.6 & 18.4 & 18.3 \\
& Minimum temperature $\left({ }^{\circ} \mathrm{C}\right)$ & 27.3 & 29.9 & 28.5 & 28.7 & 28.9 & 28.7 \\
& Maximum temperature $\left({ }^{\circ} \mathrm{C}\right)$ & 69.9 & 74.3 & 78.8 & 76.9 & 76.7 & 75.3 \\
& Relative humidity $(\%)$ & 119.4 & 156.6 & 240.8 & 178.2 & 110.1 & 161 \\
& Precipitation $(\mathrm{mm})$ & 12 & 11 & 12 & 11 & 12 & 11.6 \\
\cline { 2 - 7 } $2007 / 2008$ & Rainy days & 20.4 & 22.5 & 22 & 22 & 21.3 & 21.6 \\
& Average temperature $\left({ }^{\circ} \mathrm{C}\right)$ & 15 & 17.5 & 17.6 & 17.4 & 16.8 & 16.9 \\
& Minimum temperature $\left({ }^{\circ} \mathrm{C}\right.$ & 27.2 & 29.5 & 27.8 & 28.6 & 28 & 28.2 \\
& Maximum temperature $\left({ }^{\circ} \mathrm{C}\right)$ & 62.1 & 69.7 & 74 & 73.2 & 73.1 & 70.4 \\
& Relative humidity $(\%)$ & 241.8 & 190.3 & 90.0 & 133.9 & 129.8 & 157.2 \\
& Precipitation $(\mathrm{mm})$ & 8 & 11 & 7 & 10 & 7 & 8.6 \\
\hline
\end{tabular}


Table 3 - Area under the disease progress curve (AUDPC) for incidence, severity and percentage of defoliation caused by Xanthomonas arboricola pv. pruni in peach genotypes under natural conditions in 2007/2008.

\begin{tabular}{|c|c|c|c|}
\hline Genotypes & $\begin{array}{l}\text { AUDPC } \\
\text { Incidence }\end{array}$ & $\begin{array}{l}\text { AUDPC } \\
\text { Severity }\end{array}$ & Defoliation \\
\hline & & & $\%$ \\
\hline Conserva 1127 & $6,397.3 * a$ & $391.4 * a$ & $77.8 * \mathrm{a}$ \\
\hline Conserva 1125 & $4,546.6 \mathrm{~d}$ & $332.7 \mathrm{~b}$ & $72.4 \mathrm{a}$ \\
\hline Conserva 803 & $3,592.6 \mathrm{f}$ & $127.9 \mathrm{~b}$ & $86.6 \mathrm{a}$ \\
\hline Rubimel & $4,770.6 \mathrm{c}$ & $96.6 \mathrm{c}$ & $83.2 \mathrm{a}$ \\
\hline Conserva 1223 & $3,499.4 \mathrm{f}$ & $75.4 \mathrm{c}$ & $43.6 \mathrm{c}$ \\
\hline Conserva 655 & $3,643.7 \mathrm{f}$ & $69.1 \mathrm{c}$ & $40.7 \mathrm{c}$ \\
\hline Cascata 1070 & $5,099.5 \mathrm{~b}$ & $65.7 \mathrm{c}$ & $50.1 \mathrm{~b}$ \\
\hline Conserva 1153 & $3,055.3 \mathrm{~h}$ & $60.4 \mathrm{c}$ & $66.2 \mathrm{a}$ \\
\hline Conserva 688 & $5,028.6 \mathrm{~b}$ & $56.4 \mathrm{c}$ & $14.4 \mathrm{~d}$ \\
\hline Conserva 1187 & $4,835.8 \mathrm{~d}$ & $51.7 \mathrm{c}$ & $37.6 \mathrm{c}$ \\
\hline Santa Áurea & $2,600.7 j$ & $50.9 \mathrm{c}$ & $39.3 \mathrm{c}$ \\
\hline Tropic Beauty & $4,097.2 \mathrm{e}$ & $50.6 \mathrm{c}$ & $49.4 \mathrm{~b}$ \\
\hline Conserva 681 & $2,573.4 j$ & $39.3 \mathrm{~d}$ & $58.2 \mathrm{~b}$ \\
\hline Conserva 844 & $3,589.5 \mathrm{f}$ & $36.6 \mathrm{~d}$ & $55.9 \mathrm{~b}$ \\
\hline Cascata 962 & $3,739.4 \mathrm{f}$ & $33.5 \mathrm{~d}$ & $20.3 \mathrm{c}$ \\
\hline Conserva 1186 & $2,811.4 \mathrm{i}$ & $289.0 \mathrm{~d}$ & $41.5 \mathrm{c}$ \\
\hline Atenas & $3,281.4 \mathrm{~g}$ & $28.7 \mathrm{~d}$ & $43.3 \mathrm{c}$ \\
\hline Cascata 1055 & $3,006.5 \mathrm{~h}$ & $28.5 \mathrm{~d}$ & $37.5 \mathrm{c}$ \\
\hline Bonão & $3,606.2 \mathrm{f}$ & $26.6 \mathrm{~d}$ & $36.6 \mathrm{c}$ \\
\hline Conserva 977 & $2,362.8 \mathrm{k}$ & $19.4 \mathrm{~d}$ & $47.3 \mathrm{~b}$ \\
\hline Cascata 967 & $2,778.6 \mathrm{i}$ & $17.9 \mathrm{e}$ & $12.3 \mathrm{~d}$ \\
\hline Tropic Snow & $3,027.6 \mathrm{~h}$ & $12.7 \mathrm{e}$ & $18.7 \mathrm{~d}$ \\
\hline Cascata 1065 & $1,542.8 \mathrm{n}$ & $11.2 \mathrm{e}$ & $20.7 \mathrm{~d}$ \\
\hline Conserva 1129 & $911.6 \mathrm{p}$ & $10.8 \mathrm{e}$ & $13.1 \mathrm{~d}$ \\
\hline Olímpia & $1,978.01$ & $10.3 \mathrm{e}$ & $7.7 \mathrm{~d}$ \\
\hline Conserva 1205 & $1,450.9 \mathrm{n}$ & $10.2 \mathrm{e}$ & $27.6 \mathrm{c}$ \\
\hline Cascata 1063 & $2,313.2 \mathrm{k}$ & 8.9 e & $11.6 \mathrm{~d}$ \\
\hline Cascata 587 & $2,047.11$ & $8.8 \mathrm{e}$ & $24.0 \mathrm{~d}$ \\
\hline Conserva 985 & $1,754.0 \mathrm{~m}$ & $7.2 \mathrm{e}$ & $9.7 \mathrm{~d}$ \\
\hline Conserva 871 & $1,175.6$ o & $4.1 \mathrm{e}$ & $15.1 \mathrm{~d}$ \\
\hline Mean & $3,155.6$ & 59.1 & 38.7 \\
\hline CV. (\%) & 15.4 & 16.0 & 30.5 \\
\hline
\end{tabular}

"Means in the same column followed by different lowercase letters differ ( $p \leq 0.05$, Scott-Knott test).

Experiment II - Detached-leaf Bioassay system: Leaves from four resistant rated ('Conserva 985', 'Conserva 871', 'Conserva 1129', 'Tropic Snow') and four susceptible ('Conserva 1153', 'Bonão', 'Conserva 1125', and 'Atenas') peaches based on former field experiment were collected and evaluated for their reaction to $X$. arboricola pv. pruni using a modified detached-leaf bioassay (Randhawa and
Civerolo, 1985). The bacteria was isolated from diseased leaves and cultured, using a PDA medium (Potato Dextrose Agar). Standard inoculum was prepared by washing the $X$. arboricola pv. pruni from the nutrient agar plate with sterile distilled water. These suspensions were diluted to a final $10^{8}$ colony-forming units (CFU) $\mathrm{mL}^{-1}$. Fully expanded leaves from three plants per genotype were selected for inoculations. Bacterial suspensions were drawn into a 3-mL syringe without a needle. The syringe opening was placed firmly against the abaxial surface of the leaf, and the syringe plunger carefully pushed until a water-soaked area became visible. Care was taken not to injure the leaf with pressure from the syringe body. In all tests, each leaf was inoculated at eight sites with two leaves per replication and eight replications per genotype, resulting 128 inoculations per genotype. The control was inoculated with a $0.1 \% \mathrm{NaCl}$ solution. Two inoculated leaves were placed in each plastic box $(20 \times 12 \times 3 \mathrm{~cm})$ containing agar-water $2 \%$ where petioles were stuck. The boxes were placed in individual clear plastic bags, sprayed periodically with distilled water to maintain high moisture conditions and submitted to a 12-h photoperiod (22.5 $\mu \mathrm{mol} \mathrm{m} \mathrm{s}^{-2}$ ) at $27 \pm 1^{\circ} \mathrm{C}$.

Inoculated sites were evaluated on the $6^{\text {th }}, 8^{\text {th }}$, and $10^{\text {th }}$ day after inoculation and rated according to the disease index proposed by Civerolo and Keil (1976) with modifications: 1 - immune (no symptoms); 2 - resistant (inoculated area grey and dark vein); 3 - moderate resistance (inoculated area grey with dark vein, and watersoaking expanding beyond inoculation site); 4 - susceptible (inoculated area dark surrounded by yellow tissue); 5 - highly susceptible (necrosis spreading beyond the inoculation site, with surrounding yellow tissue and diseased areas usually dropping out).

Experiment III - trees in containers: One-year-old peaches trees of the same genotypes described in the detached-leaf bioassay were potted in $0.02 \mathrm{~m}^{3}(20 \mathrm{~L})$ containers with two parts of solarized soil: one part of sand (by volume), and watered periodically with Hoagland's modified nutrient solution. On August $28^{\text {th }}, 2008$, potted trees were moved to a greenhouse, arranged as a completely randomized design with five replications, and kept in a high humidity environment using sprinklers, at temperatures between 21 and $25^{\circ} \mathrm{C}$ and natural photoperiod $(\sim 11.5 \mathrm{~h})$. On September $14^{\text {th }}, 2008$, a high level of natural infection of $X$. arboricola pv. pruni was observed, even without inoculation. Thus, three leaves were collected, at hazard, from the middle of each plant. Leaf and lesion areas were recorded with a leaf area meter (Licor-3100). The severity of bacterial infection was expressed as a percentage of leaf area with lesions.

Data on percentage was transformed as arcsine $\sqrt{x / 100}$ whereas data of disease index was transformed by $(\mathrm{X}+0.5)^{1 / 2}$. Analysis of Variance (ANOVA) was calculated and genotypes were grouped by ScottKnott grouping test $(p \leq 0.05)$ using Genes Program Software for PC (Cruz, 2001). Pearson's correlations be- 
tween the percentage of defoliation and leaf severity rating were performed in both growing season (Exp. I).

\section{Results and Discussion}

Trees under field conditions: None of the peach genotypes were immune to $X$. arboricola pv. pruni; (Tables 2 and 3). However, susceptibility varied greatly (Tables 2 and 3), as observed by Layne (1966), Keil and Fogle (1974), Werner et al. (1986), Martins and Raseira (1996) and Kretzschmar et al. (1998). There was a significant correlation between disease severity and defoliation for both growing seasons, with $r$ values equal to 0.79 ( $p$ d" 0.01), and 0.65 ( $p$ d" 0.01), for 2006/2007 and 2007/2008, respectively. Fruit infection was low and observed in only a few genotypes such as 'Atenas', 'Conserva 1125' and 'Olimpia' (data not shown). This observation agrees with those obtained by Werner et al. (1986), which observed low correlations between fruit infection with leaf severity ratings and percentage of defoliation in North Carolina with $r$ values equal to $0.30(p=0.01)$, and $0.54(p d$ " 0.01 ), respectively. Different genes may control disease reaction in fruit and leaf tissue, as suggested by Layne (1966) and Werner et al. (1986). Both fruit and leaf infection reaction are of practical importance in peach because moderate to severely infected fruit are not marketable through normal commercial channels. Early defoliation in growing season may affect dormancy period through its negative influence on carbohydrate production and accumulation (Alves et al., 2008). As the incidence of bacterial disease in fruits was only observed for genotypes Atenas, Conserva 1125 and Olímpia, in both growing season, it is a strong indication that the other studied genotypes have good fruit resistance to $X$. arboricola pv. pruni.

For the 2006/2007 growing season, the most resistant peach genotypes were 'Tropic Snow', 'Conserva 871', 'Conserva 985' and 'Conserva 1129', while the genotype 'Conserva 1153' showed the highest level of susceptibil- ity (Table 2). Similar results were recorded during the 2007/2008 growing season, with 'Tropic Snow', 'Conserva 871', 'Conserva 985' and 'Conserva 1129' as the most resistant genotypes, while 'Conserva 1127', 'Conserva 1125', 'Conserva 803', 'Rubimel', and 'Conserva 1153' showed greater defoliation (Table 3).

The BLS severity in the field increased throughout the growing season (Figure 1). BLS infection increased in susceptible genotypes from beginning of leafing to the last observation date. The AUDPC for disease incidence and severity, and the percent of defoliation caused by BLS were greater in 2006/2007 than in 2007/2008 growing season (Tables 2 and 3 ) because the climatic conditions in 2006/2007 was more favorable for bacteria infection, with higher minimum, maximum and average temperature, higher relative humidity, and higher rainy days than in 2007/2008 (Table 1). Several studies have shown a relationship between the number of rainy days and disease occurrence. The pathogen is dependent on water for infection, colonization and dissemination. During the 2007/2008 growing season, the long periods of drought, mainly during the $3^{\text {rd }}$ observation (01.20.2008) may have contributed to a lower occurrence of BLS, resulting in a lower AUDPC for disease incidence and severity, as well as lower leaf defoliation.

Identification of resistant genotypes should be performed under optimum conditions for disease development in order to obtain a clear separation between susceptible and resistant genotypes, as observed in the 2006/ 07 cycle. Even so, it is important to highlight how difficult it is to screen genotypes for resistance to BLS using only field evaluations. Normally, high incidence and severe BLS were observed on shoots that were exposed to the action of prevailed winds. This is an indication of how important it is to protect the plants from the direct action of wind, especially in commercial orchards.

There were differences among genotypes in severity of BLS on the leaves, which ranged from 1.5 to around

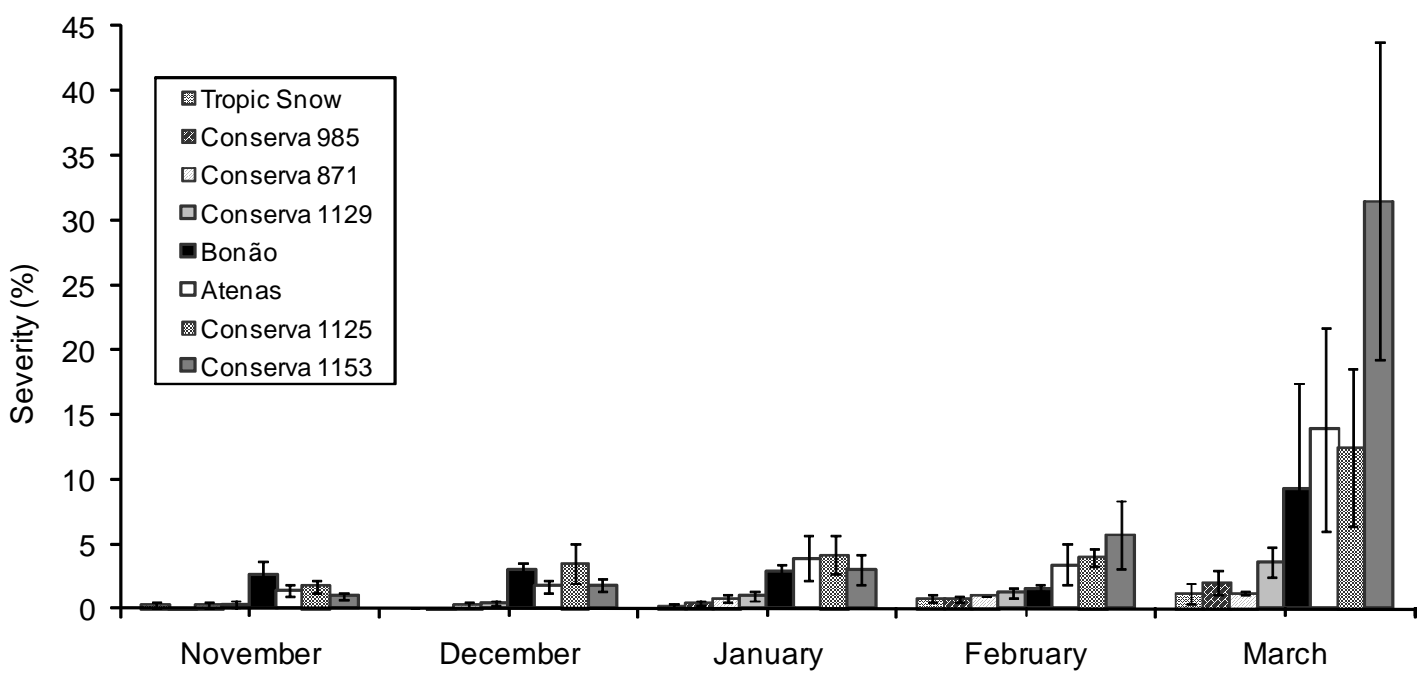

Figure 1 - Evolution of the disease severity caused by Xanthomonas arboricola pv. pruni in peach genotypes evaluated in the 20072008 growing season. 
3.5. The genotypes that showed the lowest rates of disease were 'Conserva 985' and 'Conserva 1129', while 'Conserva 1153', 'Conserva 1125' and 'Atenas' had the highest rates. 'Tropic Snow', 'Bonão' and 'Conserva 871' showed intermediate rates of infection. No immune genotypes (Figure 2) were detected, as observed by Kretzschmar et al. (1998) evaluating the response of peach varieties to $X$. arboricola pv. pruni under field conditions and after inoculation by infiltration. There were no differences among genotypes in relation to the severity of BLS under greenhouse conditions ( $p \leq 0.01$, Scott-Knott test). CV. $=58.6 \%)$. The greenhouse environment, suitable for canker development, together with a high concentration of initial inoculum, may have resulted in water-soaked spots even in the most resistant genotypes.

On the resistant genotypes, small punctiform or small lesions, with reduced or no chlorotic spots, were observed in the leaf area with a shot hole in the center of the lesion indicating a probably hypersensitive reaction (HR). This reaction is mainly determined by the metabolic capacity of the plant and could lead to a high degree of disease resistance (Pascholati and Leite, 1995). The mean temperature $\left(21.5^{\circ} \mathrm{C}\right)$ during the evaluation periods is within the range of temperature for the multiplication of bacteria $\left(16^{\circ} \mathrm{C}\right.$ to $\left.33^{\circ} \mathrm{C}\right)$ but below the critical level $\left(28^{\circ} \mathrm{C}\right)$, over which prevents the appearance of HR.

The cv. 'Tropic Snow' had a hypersensitive reaction with lesions dropping out, without halo. The genotypes considered as susceptible showed large and angular lesions with coalescence damaging vast areas, usually concentrated towards the leaf tip, with presence of a chlorotic halo. Another observed factor is that in resistant genotypes the leaves remained green, photosynthetically active, unlike susceptible genotypes for which infected leaves turn yellow and drop off. The high number of clones that were resistant to BLS in a breeding program where this disease had not previously occurred led Sherman and Lyrene (1981) to suggest dominant genes for resistance. Even so, more study must be done to elucidate the mechanism of resistance and heritability of this trait.

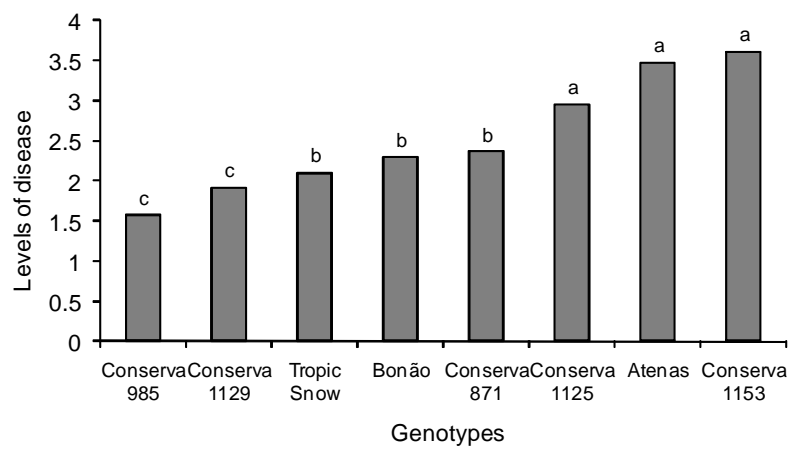

Figure 2 - Reactions of detached leaves from peach genotypes. Levels of disease are based on the scale proposed by Civerolo and Keil (1976). Means followed by same letter do not differ $(p \leq 0.01$, Scott-Knott test). CV. $=9.3 \%$.
As a conclusion, peach trees genotypes exhibited variable reactions to BLS. Peaches genotypes 'Conserva 985' and 'Conserva 1129' were identify as possible source of BLS resistance, while genotypes Conserva 1153, Conserva 1125 and 'Atenas' were susceptible.

\section{Acknowledgements}

This research was supported in part by the Embrapa Clima Temperado and CAPES (Fundação Coordenação de Aperfeiçoamento de Pessoal de Nível Superior).

\section{References}

Alves, G.; May De Mio, L.L.; Zanette, F.; Oliveira, M.C. 2008. Peach rust and its effect on the defoliation and carbohydrate concentration in branches and buds. Tropical Plant Pathology 33: 370-376. (in Portuguese, with abstract in English).

Campbell, C.L.; Madden, L.V. 1990. Introduction to Plant Disease Epidemiology. Willey, New York, NY, USA.

Citadin, I.; Assmann, A.P.; Mazaro, S.M.; Gouvêa, A.; Danner, M.A.; Malagi, G. 2008. Diagramatic scale to evaluate the severity of bacteriose in peach trees. Revista Brasileira de Fruticultura 30: 327-330. (in Portuguese, with abstract in English).

Civerolo, E.L.; Keil, H.L. 1976. Evaluation of Prunus spp resistance to Xanthomonas pruni by artificial inoculation. Fruit Varieties Journal 30: 17-18.

Cruz, C.D. 2001. GENES - Software for Experimental Statistics in Genetics. UFV, Viçosa, MG, BR. (in Portuguese).

European and Mediterranean Plant Protection Organization [EPPO]. 2006. Xanthomonas arboricola pv. pruni. EPPO Bulletin 36: 129-133.

Keil, H.L.; Fogle, H.W. 1974. Orchard susceptibility of some apricot, peach and plum cultivars and selections to Xanthomonas pruni. Fruit Varieties Journal 28: 16-19.

Kretzschmar, A.A.; Rosseto, E.A.; Martins, O.M. 1998. Resistance of some peach cultivars to Xanthomonas campestris pv. pruni inoculated by infiltration of detached leaves. Revista Brasileira de Fruticultura 20: 213-219. (in Portuguese, with abstract in English).

Layne, R.E.C. 1966. Susceptibility of apricots to bacterial spot infection of foliage and fruit. Plant Disease Reporter 50: 112-115.

Martins, O.M.; Raseira, M.C.B. 1996. Sources of bacterial spot resistance in plum cultivars. Fruits Varieties Journal 50: 156-159.

Nogueira, E.M.C.; Rodrigues Neto, J. 1982. Xanthomonas campestris pv. pruni in Prunus spp. in São Paulo State. O Biológico 48: $227-$ 229. (in Portuguese, with abstract in English).

Pascholati, S.F.; Leite, B. 1995. Host: resistance mechanism. p. 417-454. In: Bergamin Filho, A.; Kimati, H.; Amorim, L., eds. Hand-book of phytopathology: origins and concepts. Agronômica Ceres, São Paulo, SP, Brazil. (in Portuguese).

Randhawa, P.S.; Civerolo, E.L. 1985. A detached leaf bioassay for Xanthomonas campestris pv. pruni. Phytopathology 75: 1060-1063.

Raseira, M.C.B.; Nakasu, B.H. 1998. Cultivars: descriptions and recommendations. p. 29-99. In: Medeiros, C.A.B.; Raseira, M.C.B., eds. Peach culture. Embrapa-SPI, Brasília, DF, Brazil. (in Portuguese).

Rom, R.C.; Moore, J.N. 1979. Peach cultivar situation in the Midwest and Central South. Fruit Varieties Journal 33: 25-29.

Scorza, R.; Sherman, W.B. 1996. Peaches. p. 325-440. In: Janick, J.; Moore, J.N., eds. Fruit breeding: tree and tropical fruits 1. Wiley, New York, NY, USA.

Sherman, W.B.; Lyrene, P.M. 1981. Bacterial spot susceptibility in low chilling peaches. Fruit Varieties Journal 35: 74-77.

Werner, D.J.; Ritchie, D.F.; Cain, D.W.; Zehr, E.I. 1986. Susceptibility of peaches and nectarines, plant introductions, and other Prunus to bacterial spot. HortScience 21: 127-130.

Received January 08, 2010

Accepted July 26, 2010 